(C) 1980. The Genetical Society of Great Britain

\title{
CHROMOSOME PAIRING AT MEIOSIS IN HYBRIDS BETWEEN AEGILOPS AND SECALE SPECIES: A STUDY BY IN SITU HYBRIDISATION USING CLONED DNA
}

\author{
J. HUTCHINSON, V. CHAPMAN and T. E. MILLER \\ Plant Breeding Institute, Cambridge
}

Received 17.iii.80

\begin{abstract}
SUMMARY
The meiotic pairing behaviour in hybrids between Aegilops and Secale species has been examined using the technique of in situ hybridisation of tritium labelled RNA copies of cloned DNA sequences to distinguish the chromosomes. The probe used was a 480 b.p. repeat which is specific to rye, enabling the rye chromosomes to be clearly identified. It was shown that in diploid hybrids between Ae. caudata or Ae. comosa and S. cereale, pairing is mostly of the allosyndetic, Aegilops/rye type, although some autosyndetic associations also occur. In the triploid hybrid between Ae. columnaris and rye however, pairing is predominantly limited to the Aegilops chromosomes.

Examination of the patterns of labelling shown by the hybridisation of the 480 b.p. probe suggested that pairing orientation and chiasma formation are not at random. This was confirmed by in situ hybridisation of the chromosome specific, ribosomal RNA gene probe to the meiotic chromosomes of the $F_{1}$ hybrid between $A e$. comosa and $S$. cereale.
\end{abstract}

\section{INTRODUCTION}

IN the intergeneric hybrids between both diploid and tetraploid Aegilops species and Secale cereale a low level of chromosome pairing at meiosis has been reported (Karpechenko and Sorokina, 1929; Berg, 1931; Kagawa and Chizaki, 1934; Melnyk and Unrau, 1959; Majisu and Jones, 1971). Attempts have been made to try to identify the chromosomes involved in the pairing on the basis of differences in chromosome size (Melnyk and Unrau, loc. cit.; Majisu and Jones, loc. cit.). At meiosis, it is not always possible to distinguish the rye chromosomes on the basis of length, and so the rye chromosomes have sometimes been distinguished by their thickness (Majisu and Jones, loc. cit.).

The development of the technique of in situ hybridisation (Gall and Pardue, 1971), whereby tritium labelled RNA copies (cRNA) of DNA sequences are hybridised to mitotic and meiotic chromosomes, provides a valuable method of chromosome identification. Recently, repeated sequences from Secale cereale have been completely purified by cloning in bacterial plasmids (Bedbrook et al., 1980). One of these sequences, the 480 b.p. sequence, was shown to be absent from, or present in very low copy number, in the very closely related Secale species, $S$. silvestre. It was similarly undetectable in bread wheat, Triticum aestivum. The 480 b.p. sequence is therefore also unlikely to be present in Aegilops species. In situ hybridisation of this probe should provide a means of distinguishing the chromosomes of rye from those of the Aegilops species. This new technique 
has therefore been used to examine the meiotic pairing behaviour in the $\mathrm{F}_{1}$ hybrids between two diploid Aegilops species, Ae. comosa and Ae. caudata, and one tetraploid species, Ae. columnaris, with diploid rye, $S$. cereale.

\section{MATERials AND METHODS}

(i) Crosses

Single accessions of the diploid species, Aegilops comosa (MM, $2 n=14)$ and $A$ e. caudata $(\mathrm{CC}, 2 n=14)$, together with the tetraploid Ae. columnaris $\left(C^{\mathrm{u}} \mathrm{C}^{\mathrm{u}} \mathrm{M}^{\mathrm{c}} \mathrm{M}^{\mathrm{c}}, 2 n=4 x=28\right)$ were crossed during summer 1979 with Secale cereale c.v. Petkus Spring $\left(\mathrm{R}^{\mathrm{c}} \mathbf{R}^{\mathrm{c}}, 2 n=14\right)$. The rye was used as the pollen parent, and embryo culture was used throughout.

\section{(ii) Cytology}

Excised root-tips were pre-treated with either: (a) A saturated solution of 1 -bromonaphthalene for $4 \frac{1}{2}$ hours at $23-25^{\circ} \mathrm{C}$ or (b) 0.025 per cent colchicine for 6 hours at $27^{\circ} \mathrm{C}$. After fixation in $1: 3$ acetic alcohol, the root-tips were dissected out in 45 per cent acetic acid following the procedure outlined by Appels et al. (1978).

Hybrid plants were grown in an environmental cabinet maintained at $20^{\circ} \mathrm{C}$ with an 18 hour day length. Anthers at the correct stage of division were fixed in $1: 3$ acetic alcohol and stored at $4^{\circ} \mathrm{C}$ until required. For in situ hybridisation, anthers were slit open in a very small quantity of 45 per cent acetic acid, and gently teased under a dissecting microscope until the pollen mother cells (PMC's) were released. The anther wall was then removed. After covering with an acid-washed cover slip, the PMC's were squashed gently without heating. The cover slip was then removed after freezing in liquid nitrogen, and the slide was transferred to 96 per cent ethanol for 1 hour before being air dried.

(iii) In situ hybridisation

The in situ hybridisation, which was based on the method of Gall and Pardue, (1971) was carried out as follows:

\section{(a) Pre-treatment}

Prior to hybridisation with the ribosomal RNA gene probe only, slides were incubated for $1 \frac{1}{2}$ hours in $100 \mu \mathrm{g} / \mathrm{ml}$ pancreatic RNase (prepared from a $10 \mathrm{mg} / \mathrm{ml}$ stock which had been incubated at $80^{\circ} \mathrm{C}$ for 10 mins to inactivate DNases) and 500 units $/ \mathrm{ml} T_{1}$ RNase in $2 \times \mathrm{SSC}$ at $37^{\circ} \mathrm{C}$. Slides were then washed 3 times in $2 \times \mathrm{SSC}$ for 5 minutes at room temperature followed by dehydration through 70 per cent and 96 per cent ethanol.

\section{(b) Denaturation and hybridisation}

Following air drying, the ${ }^{3} \mathrm{H}$ cRNA probe in $7 \mu \mathrm{l}$ of $3 \times \mathrm{SSC}: 50$ per cent formamide was placed over the preparation, covered with an acid-washed coverslip and sealed with rubber solution. 50,000-100,000 cpm of cRNA were applied per slide. The slide and probe was then dipped in water at $67^{\circ} \mathrm{C}$ 
for 30 seconds to denature the DNA of the chromosomes. Hybridisation took place for $12-16$ hours at $39-40^{\circ} \mathrm{C}$.

\section{(c) Post-hybridisation}

After hybridisation, the coverslip was removed, and the slides were washed 3 times in $2 \times \mathrm{SSC}$ at $45^{\circ} \mathrm{C}(5 \mathrm{~min}$ per wash). Poorly matched hybrids were then melted off by incubating for 15 minutes in $1 \times \mathrm{SSC}$ at $60^{\circ} \mathrm{C}$. The slides were then washed for 5 minutes in $2 \times \mathrm{SSC}$ at $37^{\circ} \mathrm{C}$, before being incubated for 30 minutes at $37^{\circ} \mathrm{C}$ in $2 \times \mathrm{SSC}$ containing $100 \mu \mathrm{g} / \mathrm{ml}$ pancreatic RNase and 2 units/ml $T_{1}$ RNase. The slides were then washed six times in $2 \times \mathrm{SSC}$ at room temperature, before being dehydrated through 70 per cent and 96 per cent ethanol and air dried. Slides were dipped in a 50 per cent solution of Ilford $\mathrm{K} 2$ emulsion in gel form, air dried and stored over silica gel in light tight boxes at $4^{\circ} \mathrm{C}$. After the correct exposure time, the autoradiographs were developed in Kodak D19 developer and fixed in Kodak metafix. After rinsing, the slides were stained for 3 minutes in Carbol fuchsin stock stain (Darlington and La Cour, 1969). The slides were then rinsed with water, air dried and mounted in immersion oil.

\section{(iv) Radioactive $R N A$ probes}

(a) Rye 480 b.p. probe

This probe was tritium labelled cRNA transcribed by $E$. coli RNA polymerase (Gall and Pardue, loc. cit.) from the plasmid pSC 210. This chimaeric plasmid consists of a 480 b.p. sequence from rye in the vector plasmid pBR 322 (Bedbrook et al., loc. cit.). Rye contains over $10^{6}$ copies of the 480 b.p. sequence which contains one MBO II and Taq I restriction endonuclease site.

\section{(b) Ribosomal RNA gene probe}

This probe was tritium labelled cRNA transcribed by $E$. coli RNA polymerase from plasmid pHV 256. This chimaeric plasmid consists of a single barley ribosomal gene repeating unit (i.e., 18S, 5.8S, $25 \mathrm{~S}$ rRNA coding sequences and associated spacer DNAs), in the vector plasmid pACYC 184 (Gerlach and Bedbrook, 1979).

\section{(v) DNA isolation and preparation}

DNA was isolated from green leaves following the method of Graham (1978). Following ethanol precipitation the pellet was dissolved in $2 \mathrm{ml}$ of $50 \mathrm{mM}$ Tris $\mathrm{HCl} 10 \mathrm{mM}$ EDTA $p \mathrm{H} 8.0$ and digested with pronase $\left(500 \mu \mathrm{g} / \mathrm{ml}\right.$, previously autodigested at $37^{\circ} \mathrm{C}$ for 2 hours) for 4 hours at $37^{\circ} \mathrm{C}$. The DNA was then purified by banding in $\mathrm{CsCl}$ containing ethidium bromide (Bedbrook et al., loc. cit.) before being dialysed against $10 \mathrm{mM}$ Tris $\mathrm{HCl} 0.25 \mathrm{mM}$ EDTA $p \mathrm{H} \mathrm{8.0.} \mathrm{The} \mathrm{DNA's} \mathrm{at} \mathrm{various} \mathrm{concentrations}(S$. cereale $\{2 \cdot 5 \mu \mathrm{g}\}$, Ae. columnaris $\{5 \mu \mathrm{g}$ and $1 \cdot 5 \mu \mathrm{g}\}$, Ae. comosa $\{4 \cdot 5 \mu \mathrm{g}\}$ and $A$ e. caudata $\{2 \cdot 5 \mu \mathrm{g}\})$ were digested with the restriction endonuclease Taq I (New England Bio Labs) and fractionated by electrophoresis on a 1.5 
per cent agarose gel. The DNA's were then transferred from the agarose gels to millipore paper by the method of Southern (1975). A ${ }^{32} \mathrm{P}$ labelled cDNA probe was prepared by nick-translation of the 480 b.p. DNA sequence (Maniatis et al., 1975). The filters were then pre-treated in buffer for 3 hours before being hybridised for 16 hours with $10^{6} \mathrm{cpm}$ of this probe under the conditions described by Wahl et al. (1979), followed by thorough washing in $3 \times \mathrm{SSC}, 2 \times \mathrm{SSC}$ and $1 \times \mathrm{SSC}$ at $60^{\circ} \mathrm{C}$. Autoradiographs on $\mathrm{X}$-ray film were developed after 1 and 8 days exposure.

\section{Results}

(i) Identification of rye chromosomes using the 480 b.p. sequence

In order to study the Aegilops and rye chromosomes during meiosis by in situ hybridisation, it was first necessary to ensure that the nucleic acid probe, isolated from the rye genome, was essentially absent from the Aegilops species. The nucleic acid probe chosen was the 480 b.p. sequence from rye cloned in a bacterial plasmid. Rye contains over $10^{6}$ copies of this sequence and these sequences are localised predominantly at the telomeres of the chromosomes (Bedbrook et al., loc. cit.). The absence, or low multiplicity of these sequences in the Aegilops species was demonstrated in two ways. Firstly, by in situ hybridisation, and secondly, by hybridisation to DNA bound to nitrocellulose filters. The latter method is considerably more sensitive. Fig. 1 shows the 480 b.p. sequence hybridised to metaphase chromosomes of the $\mathrm{F}_{1}$ hybrid between Ae. caudata and S. cereale. Only seven chromosomes are labelled and the labelling pattern is that of seven rye chromosomes. In separate tests on Aegilops species very little convincing labelling occurred over the chromosomes and it could be concluded that the 480 b.p. sequence was not detectable in Aegilops chromosomes by in situ hybridisation. In the biochemical assays, DNA's extracted from Aegilops comosa, Ae. caudata, Ae. columnaris and Secale cereale were digested with the restriction endonuclease Taq I and the fragments fractionated on 1.5 per cent agarose gel. After transfer to nitrocellulose paper by the method of Southern (1975), the DNA was hybridised to a ${ }^{32} \mathrm{P}$ labelled probe of the 480 b.p. sequence. The results shown in fig. 2 also demonstrate that the 480 b.p. sequence is effectively absent from the Aegilops species. The 480 b.p. sequence is therefore a very suitable probe for distinguishing rye and Aegilops chromosomes.

\section{(ii) Pairing between Aegilops and Secale chromosomes}

Hybridisation of the 480 b.p. probe to PMC's at first metaphase of meiosis shows that the rye and the Aegilops chromosomes can be clearly distinguished (fig. 3a, b). The meiotic chromosomes are slightly swollen due to the in situ procedure, but it is nevertheless possible to analyse the pairing behaviour of the rye and Aegilops chromosomes.

Table 1 shows the mean chromosome pairing at first metaphase in the various $F_{1}$ hybrids. The two diploid hybrids show a similar level of pairing, which although fairly low, is slightly higher than previously published data (Majisu and Jones, loc. cit.). Pairing in the diploid hybrids was largely limited to rod bivalent formation although infrequent ring bivalents and 


\section{Plate I}

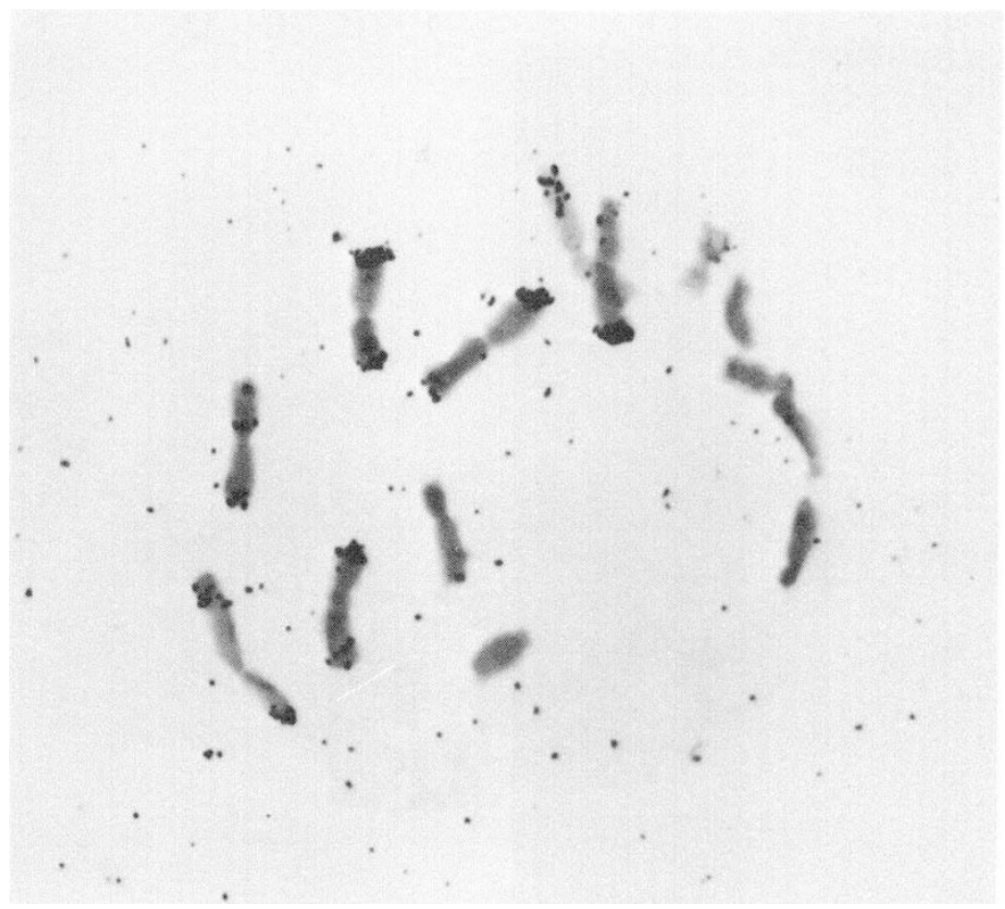

FIG. 1.-In situ hybridisation of the 480 b.p. rye sequence to the mitotic chromosomes of the $F_{1}$ hybrid between Aegilops caudata and Secale cereale. The seven rye chromosomes are clearly labelled at one or both telomeres while the Aegilops chromosomes are unlabelled. 
Plate II

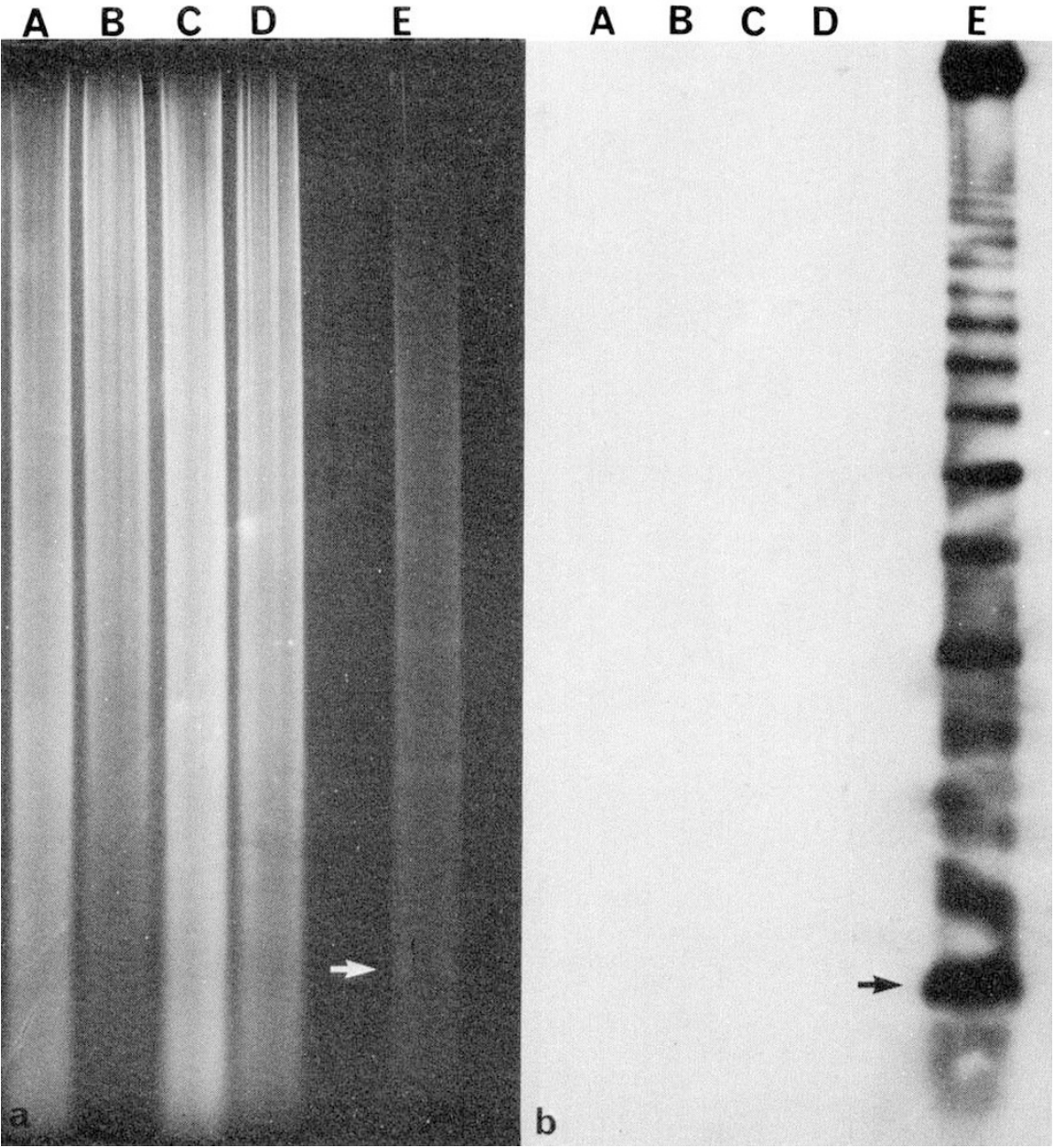

FIG. 2.-(a) DNA's from Ae. columnaris (tracks A and D), Ae. caudata (track B), Ae. comosa (track $C$ ) and $S$. cereale (track E) were digested with the restriction endonuclease Taq I and fractionated on a 1.5 per cent agarose gel. Gel electrophoresis (from top to bottom) was at $20 \mathrm{~mA} / \mathrm{gel}$.

(b) Hybridisation of the 480 b.p. ${ }^{32} \mathrm{P}$ probe to nitrocellulose blots of the gel shown in the adjacent fig. 2a. The autoradiographs and gel pictures are aligned with monomers arrowed and clearly show that the probe hybridised only to the rye in Track E. 
trivalents were observed. In the triploid, Ae. columnaris $\times S$. cereale hybrid, however, trivalent formation was quite frequent. This is in agreement with the data from crosses involving other tetraploid Aegilops species and $S$. cereale (Berg, loc. cit., Kagawa and Chizaki, loc. cit., Majisu and Jones, loc. cit.).

\section{TABLE 1}

Mean chromosome pairing at first metaphase of meiosis. (Ranges in parenthesis)

\begin{tabular}{|c|c|c|c|c|c|}
\hline Hybrid & Plant & $\begin{array}{l}\text { Number of } \\
\text { cells }\end{array}$ & I & II & III \\
\hline Ae. caudata $\times S$. cereale & 1 & 20 & $\begin{array}{l}11 \cdot 40 \\
(8-14)\end{array}$ & $\begin{array}{l}1 \cdot 05 \\
(0-4)\end{array}$ & $\begin{array}{c}0 \cdot 1 \\
(0-1)\end{array}$ \\
\hline \multirow[t]{2}{*}{ Ae. comosa $\times S$. cereale } & 1 & 30 & $\begin{array}{c}10 \cdot 49 \\
(6-14)\end{array}$ & $\begin{array}{l}1 \cdot 77 \\
(0-4)\end{array}$ & - \\
\hline & 2 & 50 & $\begin{array}{l}11 \cdot 70 \\
(8-14)\end{array}$ & $\begin{array}{l}1 \cdot 06 \\
(0-3)\end{array}$ & $\begin{array}{c}0 \cdot 06 \\
(0-1)\end{array}$ \\
\hline \multirow[t]{2}{*}{ Ae. columnaris $\times$ S. cereale } & 1 & 50 & $\begin{array}{r}14 \cdot 39 \\
(12-19)\end{array}$ & $\begin{array}{l}2 \cdot 68 \\
(1-5)\end{array}$ & $\begin{array}{c}0.42 \\
(0-3)\end{array}$ \\
\hline & 2 & 30 & $\begin{array}{r}14 \cdot 50 \\
(10-19)\end{array}$ & $\begin{array}{l}2 \cdot 89 \\
(0-5)\end{array}$ & $\begin{array}{c}0.23 \\
(0-1)\end{array}$ \\
\hline
\end{tabular}

The observed bivalents and trivalents may consist of either autosyndetic associations within the Aegilops (aa) or within the rye (rr) complements, or of allosyndetic associations involving both rye and Aegilops chromosomes (ar). Two such allosyndetic bivalents are shown in fig. 3a. Table 2 shows the frequency of the various types of association. In the diploid hybrids, the majority of the bivalents are of the allosyndetic, Aegilops-rye type, although some autosyndetic associations also occur. In the triploid hybrid between Ae. columnaris and rye, however, the majority of the bivalents and trivalents involve only the Aegilops chromosomes.

Examination of the univalents at meiosis showed that there were two patterns of labelling, namely either one, or both of the telomeres of the rye chromosomes were labelled by the probe. Over all data, and all hybrids, including the bivalents, the ratio of 1 telomere labelled to both telomeres labelled was $2 \cdot 6: 4 \cdot 4$. Although the labelling of sites does to some extent vary depending upon the time of autoradiographic exposure, this ratio is in general agreement with the results observed in studies on the mitotic chromosomes of wheat-rye addition lines (J. Jones, unpublished). It is therefore possible to further classify Aegilops/rye chromosome associations into groups according to the position of the label on the rye chromosomes. Since most of the associations in the triploid hybrids involve only the Aegilops chromosomes, only the rod bivalents in the diploid hybrids were considered. A diagrammatic representation of the different patterns of labelling, together with the overall frequency of bivalents in each category are shown in table 3 . A comparison of the frequencies of bivalents where the rye chromosome has one telomere labelled with those where both telomeres are labelled, showed a ratio of $34: 61$. This does not deviate significantly from the ratio of $2 \cdot 6: 4 \cdot 4\left(\chi^{2}=0 \cdot 07, p=0 \cdot 8\right)$. This indicates that, in the present material, all rye chromosomes have an equal chance of pairing with Aegilops chromosomes. 


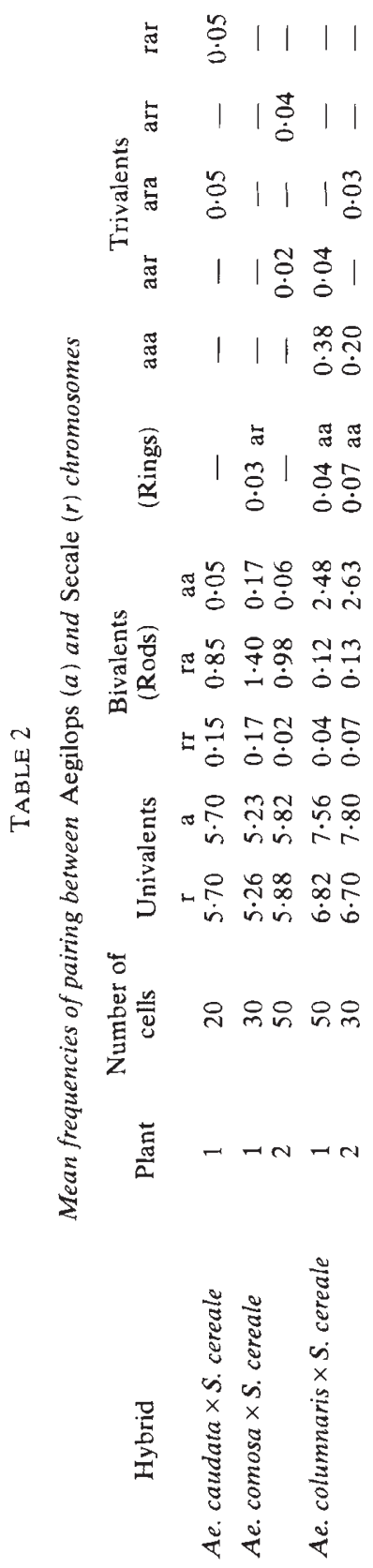



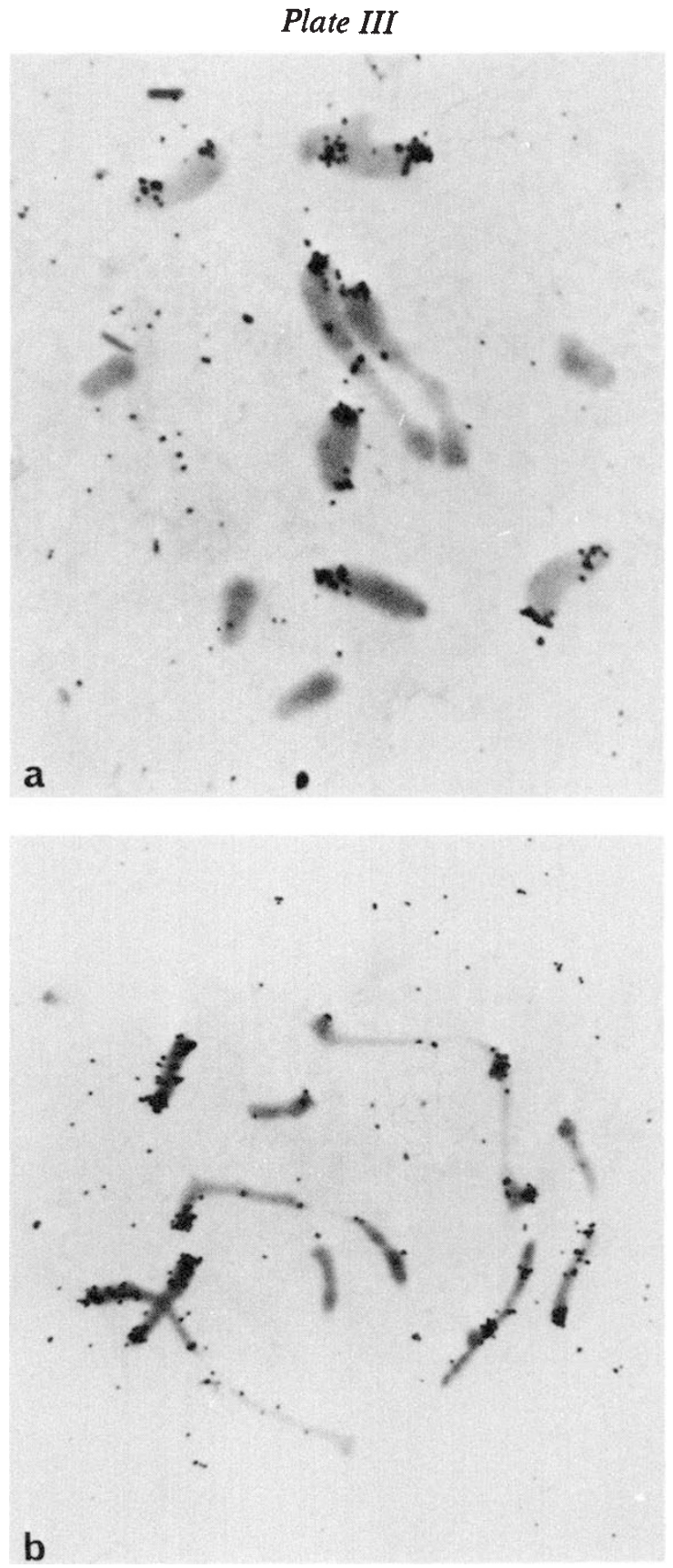

FIG. 3.-In situ hybridisation of the 480 b.p. rye probe to the meiotic chromosomes of $F_{1}$ hybrids between Aegilops species and Secale cereale.

(a) Ae. caudata $\times S$. cereale $\mathrm{F}_{1}$ showing two Aegilops-rye bivalents together with 5 labelled rye univalents and 5 unlabelled Aegilops univalents (one of which is partially obscured by a sye univalent).

(b) Ae. comosa $\times S$. cereale $\mathrm{F}_{1}$ showing 4 Aegilops-rye bivalents. 


\section{TABLE 3}

Frequencies of rod bivalents where one telomere of the rye chromosome is labelled by the 480 b.p. probe, to those where both telomeres are labelled

\begin{tabular}{lrrrr}
\multicolumn{1}{c}{ Hybrid } & Plant & Pattern of labelling \\
Ae. caudata $\times$ S. cereale & 1 & 9 & 14 & 2 \\
Ae. comosa $\times$ S. cereale & 1 & 14 & 10 & $\frac{8}{2}$ \\
Total & 2 & 38 & $\underbrace{30}_{34}$
\end{tabular}

It will be observed that there are two possible labelling patterns where the rye chromosome has only one telomere labelled. Table 3 shows that very few bivalents were recorded in which the labelled site occurred on the chromosome arm involved in chiasma formation. This observation therefore implies that the pairing orientation and chiasma formation is not entirely at random. Further evidence for this comes from the in situ hybridisation of a ribosomal RNA gene probe to the meiotic chromosomes of the $\mathrm{F}_{1}$ hybrid between Ae. comosa and $S$. cereale.

\section{(iii) Examination of Aegilops-Rye pairing with the chromosome specific, ribosomal $R N A$ gene, probe}

The ribosomal RNA gene probe was shown to hybridise predominantly to one site on one pair of chromosomes in the chromosome complement of $S$. cereale c.v. Petkus Spring. This was in agreement with previous in situ hybridisations to the rye cultivar King II (Miller, Gerlach and Flavell, in preparation). In situ hybridisation to the mitotic chromosomes of $A e$. comosa however showed that although likewise there was one pair of chromosomes with a major ribosomal gene site, there were also occasional scatters of silver grains, which may possibly indicate other ribosomal RNA gene clusters. The expression of label at different sites is obviously dependent upon the number of copies of the sequence, the specific activity of the cRNA probe used and also the autoradiographic exposure time. It is therefore possible that under different experimental conditions a second, much smaller, ribosomal gene cluster might be observed in Ae. comosa. Under the experimental conditions used here, however, in situ hybridisation of the ribosomal RNA gene site to meiotic chromosomes of the $F_{1}$ hybrids between $A$ e. comosa and $S$. cereale showed only the major sites of the rye and Aegilops chromosomes.

Since it has already been shown that in the diploid hybrids most of the bivalents were allosyndetic (table 2), then if pairing between chromosomes were at random, and there are two labelled chromosomes per cell, any one labelled chromosome has a chance of approximately 1 in 6 of pairing with another labelled chromosome. Table 4 shows the frequency of bivalents with one chromosome labelled, and with both chromosomes labelled. It will 
TABLE 4

Patterns of labelling with the ribosomal RNA gene probe in bivalents in the $F_{1}$ hybrid between Ae. comosa and $\mathrm{S}$. cereale

Bivalents with one chromosome labelled

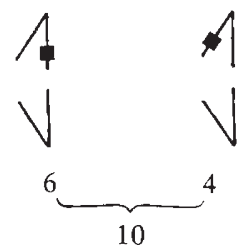

Bivalents with both chromosomes labelled

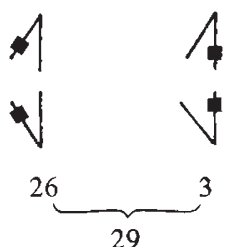

be observed that there are far more bivalents with both chromosomes labelled than might be expected. It can therefore be concluded that the $S$. cereale ribosomal chromosome is more likely to pair with the major ribosomal chromosome of Aegilops than with any other chromosome.

Further examination of rod bivalents in which both chromosomes were labelled showed only two types of pattern, namely, either the label was located on the distal arms of the bivalent (fig. 4), or on the proximal arms of the bivalent (table 4). This therefore implied that the chromosomes were specifically orientated at pairing. In addition, 26 bivalents of the distal type were recorded, as compared with 3 bivalents of the proximal type. This again indicates that chiasma formation was more likely to occur in one arm than another, and was not random.

\section{Discussion}

Several conclusions may be drawn from these experiments. First, in diploid Aegilops $\times$ Secale hybrids, the Aegilops chromosomes are more likely to pair with Secale chromosomes than with other Aegilops chromosomes. Pairing is therefore not random, which suggests that there is partial homology between Secale and Aegilops chromosomes. This is in agreement with the conclusions reached by Melnyk and Unrau (loc. cit.) based on studies of the meiotic pairing between $A e$. squarrosa and $S$. cereale in which the Aegilops and rye chromosomes were differentiated on the basis of size, although it does not agree with the results of Majisu and Jones (loc. cit.). It should be pointed out, however, that the overall level of pairing obtained in the experiments of Majisu and Jones was lower than that reported here, and may reflect a lower level of allosyndetic pairing in that material. In contrast to the diploid hybrids, in the triploid hybrid between $A e$. columnaris and $S$. cereale, pairing and chiasma formation was largely limited to the Aegilops chromosomes. This suggests that, as expected, the genomes $\mathrm{C}^{\mathrm{u}}$ and $\mathrm{M}^{\mathrm{c}}$ which constitute $A e$. columnaris are more closely related to each other than they are to the $S$. cereale $\mathrm{R}^{\mathrm{c}}$ genome.

The second conclusion to be drawn, particularly from the experiments with the ribosomal RNA gene probe, is that, during pairing, the chromosomes pair in a specific orientation, not at random. 


\section{Plate IV}

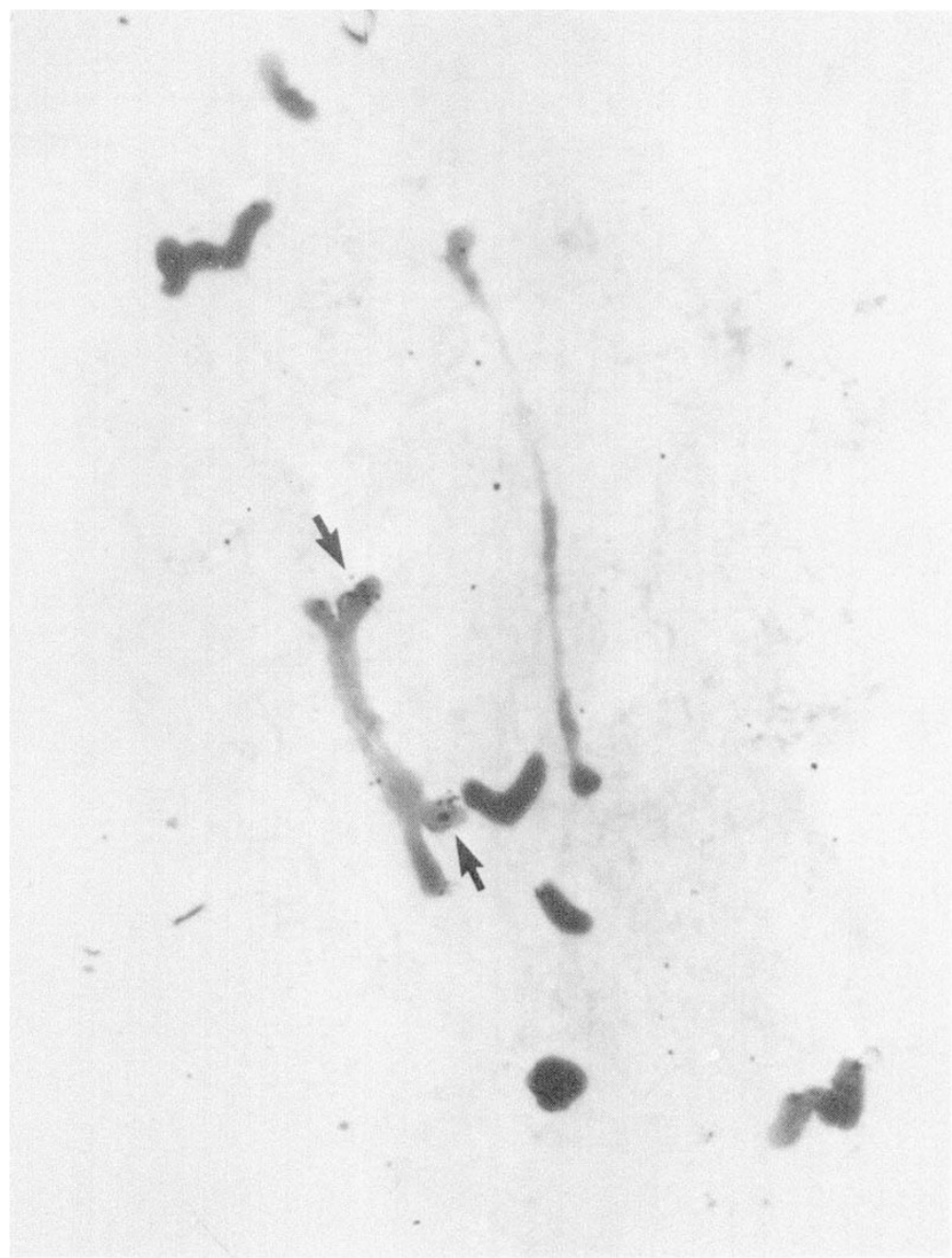

FIG. 4.-In situ hybridisation of the ribosomal RNA gene probe to the meiotic chromosomes of the $F_{1}$ hybrid between $A e$. comosa and $S$. cereale. The ribosomal RNA gene clusters are located on the distal arms of the bivalent (arrowed). 
This observation is reinforced by the finding that chiasmata occurred most often in particular chromosome arms, namely in the chromosome arms which do not possess the ribosomal gene clusters. Since in most cells the nucleoli are formed at the chromosomal sites of these ribosomal gene clusters, this suggests that there may be some restriction upon pairing or chiasma formation in the vicinity of the nucleolus. Indeed, reduced chiasma frequencies in this region were observed previously in studies on the chiasma distribution along the chromosomes of Vicia faba (Hutchinson, 1973). It is therefore reasonable to infer that the nucleolus itself could be an impediment to effective pairing at zygotene and pachytene. There is, however, an alternative explanation for the reduced pairing observed in the chromosome arms possessing the ribosomal gene clusters. The in situ studies showed that these ribosomal gene clusters were located on the shorter arms of the chromosomes of both rye and Aegilops. It is well known that there is a close correlation between chiasma frequency and chromosome length (Mather, 1937). Recent examination of pairing in telocentric lines of wheat has shown that this relationship also extends to the chromosome arms, since more chiasmata were observed in the long than in the short chromosome arms (Sallee and Kimber, 1978). It is therefore possible that the preferential location of chiasmata in particular chromosome arms observed in the Aegilops $\times$ Secale hybrids could be related to the differences in the length of the chromosome arms.

Thirdly, the experiment with the ribosomal RNA gene probe suggested that the $S$. cereale chromosome carrying the ribosomal gene cluster was more likely to pair with the Ae. comosa chromosome carrying the major ribosomal gene cluster than with any other chromosome. Although it cannot be verified by the present experiments, it is probable that these chromosomes are homoeologous and therefore that the pairing in these hybrids is largely homoeologous.

Finally, these experiments suggest that, at the diploid level, the intergeneric chiasmata associations between Aegilops and Secale would permit recombination and the transfer of genetic information between the species, if viable gametes were produced. At higher ploidy levels, however, this might be less likely due to preferential pairing of the more closely related genomes.

These experiments demonstrate the value of the technique of in situ hybridisation for investigating chromosome behaviour at meiosis. Although, in this example, it might be possible to distinguish the Secale chromosomes from the Aegilops chromosomes by means of Giemsa banding, as in wheat-rye hybrids (Mettin et al., 1976), there are many other situations in which this staining technique is not applicable. The development of different DNA probes will therefore be of great value for identifying chromosomes in future studies.

\section{REFERENCES}

APPELS, R., DRISCOLL, C., AND PEACOCK, W. J. 1978. Heterochromatin and highly repeated DNA sequences in rye (Secale cereale). Chromosoma (Berl.), 70, 67-89.

BEDBROOK, J. R., JONES, J., O'DELL, M., THOMPSON, R. D., AND FLAVELL, R. B. 1980. A molecular description of telomeric heterochromatin in Secale species. Cell, (in press).

BERG, K. H. VON 1931. Autosyndese in Aegilops triuncialis L. $\times$ Secale cereale L. Z. Zucht., 17, 55-69 
DARLington, C. D., AND LA COUR, L.F. 1969. The Handling of Chromosomes. George Allen and Unwin Ltd.

GALL, J. G., AND PARDUE, M. L. 1971. Nucleic acid hybridization in cytological preparations. In Methods in Enzymology, eds, Grossman and Moldave. Academic Press, New York.

GERLACH, W. L., AND BEDBROOK, J. R. 1979. Cloning and characterization of ribosomal RNA genes from wheat and barley. Nucleic Acids Res., 7, 1869-1886.

GRAHAM, D. E. 1978. The isolation of high molecular weight DNA from whole organisms or large tissue masses. Analytical Biochem., 85, 609-613.

HUTCHINSON, J. 1973. In Chromosome selection in Secale. PhD Thesis, University of Wales, U.K.

KAGAWA, F., AND CHIZAKI, Y. 1934. Cytological studies in genus hybrids of some cereals and a related plant. Ustonomiya Agr. Coll. Bull., 5, 53-65.

KARPECHENKO, C. D., AND SOROKINA, O. N. 1929. The hybrids of Aegilops triuncialis L. with rye. Bull. Appl. Botany Genet. and Plant Breeding (U.S.S.R.), 20, 536-584.

MAJISU, B. N., AND JONES, J. K. 1971. Aegilops $\times$ Secale hybrids: The production and cytology of diploid hybrids. Genet. Res. Camb., 17, 17-31.

MANIATIS, T., JEFFREY, A., AND KLEID, D. G. 1975. Nucleotide sequence of the rightward operator of Phage A. Proc. Natl. Acad. Sci. U.S.A., 72, 1184-1188.

MATHER, K. 1937. The determination of position in crossing-over. II. The chromosome length-chiasma frequency relation. Cytologia Fujii Jub., 514-536.

MELNYK, J., AND UNRAU, J. 1959. Pairing between chromosomes of Aegilops squarrosa L. var. Typica and Secale cereale L. var. Prolific, Canad. J. Genet. Cytol., 1, 21-25.

METTIN, D., SCHLEGEL, R., BLÜTHNER, W.-D., AND WEINRICH, M. 1976. Giemsa-Banding von MI-Chromosomen bei Weizen-Roggen-Bastarden. Biol. Zbl., 95, 35-41.

SALLEE, P. J., AND KIMBER, G. 1978. An analysis of the pairing of wheat telocentric chromosomes. In Proceedings of the fifth international wheat genetics symposium, ed. Ramanujam, S. New Delhi, India. vol. 1, session III Alien Genetic Material. pp. 408-419.

SOUTHERN, E. M. 1975. Detection of specific sequences among DNA fragments separated by gel electrophoresis. J. molec. Biol., 98, 5031517.

WAHL, G. M., STERN, M., AND STARK, G. R. 1979. Efficient transfer of large DNA fragments from agarose gels to diazobenzyloxymethyl-paper and rapid hybridization by using dextran sulfate. Proc. Natl. Acad. Sci. U.S.A., 76, 3683-3687. 